\title{
Photosynthetic characteristics and diversity of freshwater Synechococcus at two depths during different mixing conditions in a deep oligotrophic lake
}

\author{
Cristiana CALLIERI*, Gianluca CORNO, Emanuele CARAVATI, Silvia GALAFASSI, Michel BOTTINELLI ${ }^{1)}$ and \\ Roberto BERTONI
}

CNR Institute of Ecosystem Study, Largo Tonolli 50, 28922 Verbania, Italy

${ }^{1)}$ ICM - Istituto Cantonale di Microbiologia, Via Mirasole 22a, 6500 Bellinzona, Switzerland

*e-mail corresponding author: c.callieri@ise.cnr.it

\begin{abstract}
We studied the photosynthetic characteristics and genetic diversity of Synechococcus assemblages at two different light and mixing conditions in a deep oligotrophic lake (Lake Maggiore, Northern Italy). Sampling was performed at the beginning of summer stratification, when the base of the photic zone was isolated by the presence of a shallower thermocline, and during late summer, when the mixing layer extended below the photic zone. Two depths were sampled (15\% and $1 \%$ of surface PAR). To study the diversity of Synechococcus, we used a classical molecular fingerprinting technique (Denaturing Gradient Gel Electrophoresis, DGGE) with ambient samples and sequencing of the prominent bands. The ecotypes selected within the samples from different depths were different in photosynthetic characteristics and grew in a range of nutrient concentrations. The OTUs colonizing different niches in the water column did not show any significant clustering. However, the OTU richness was significantly different at the two depths in spring, reaching the highest values at $15 \%$ of surface PAR. Cluster analysis of DGGE lanes provided evidence of different community compositions between spring and late summer. Sequencing of the most prominent bands showed one spring OTU affiliated to the Synechococcus subalpine cluster I, with 100\% similarity to LM94, MW76B2 and MW15\#2 (sensu Crosbie et al. 2003a), not present in late summer. Another OTU present both in spring and late summer showed 100\% similarity to MH301, a strain near to subalpine cluster II. Our results support the coexistence of ecotypes in the vertical gradients, rapidly acclimating and performing differently in the microhabitats.
\end{abstract}

Key words: freshwater picocyanobacteria, Synechococcus spp., photosynthetic characteristics, genetic diversity, Lake Maggiore

\section{INTRODUCTION}

In freshwater ecosystems Synechococcus-like cyanobacteria dominate both the surface and deep layers (Stockner et al. 2000) and can be present as solitary single cells or in microcolonies (Passoni \& Callieri 2001; Komárková 2002; Crosbie et al. 2003b), with more morphotypes than marine environments. Whether microenvironment peculiarities determine different genetic traits is in debate. From ecological studies, we know that Synechococcus, like many prokaryotes, is highly plastic and, in lakes, can acclimate to different environmental conditions and irradiance levels by adjusting their pigment composition (Hauschild et al. 1991; Callieri 1996; Vörös et al. 1998). By phylogenetic study of the $16 \mathrm{~S}$ rDNA, the genus Synechococcus is known to be polyphyletic (Robertson et al. 2001), but the identification of species inside this taxon is still unclear. The large number of isolated strains suggests that closely related taxa have undergone widespread dispersal (Crosbie et al. 2003a) and contradicts the evidence that strain clusters developed similar ecotypes during independent adaptive radiations (Ernst et al. 2003). These molecular genetic studies claim that there is an urgent need for more data acquisition and the development of different approaches. A general consensus on the importance of the paral- lel study of genetic and ecological characteristics of this taxon is necessary for a comprehensive evaluation of the different ecotypes.

To get insight into the freshwater Synechococcus ecotypes/genotypes in a deep oligotrophic subalpine lake we compared its photosynthetic characteristics and diversity (1) at two depths under different irradiances, and (2) at spring and late summer peaks of abundance during different mixing conditions

To study the genetic diversity of Synechococcus we used an application of DGGE (Denaturing Gradient Gel Electrophoresis) (Muyzer et al. 1993), one of the classical molecular fingerprinting techniques. DGGE gives information on OTU diversity and richness and, through sequencing of the gel bands, we can compare the sample to sequences published in genomic databases in order to infer phylogenetic affiliation. In the marine environment, researchers have found compartmentalization of Prochlorococcus and Synechococcus clades in the horizontal and vertical "space" at contrasting environmental conditions (Fuller et al. 2006). However, in freshwater, as far as we know, no data exist on the depth-dependent genetic diversity of Synechococcus, or its possible correlation with physiological adaptations. Similarly, we set out to compare the diversity of Synechococcus to the photosynthetic performance of subpopulations (sensu Ernst et 
al. 2000). We addressed the difficult question of whether, in lakes, the genus Synechococcus consists of multiple coexisting ecotypes that are genetically closely related but physiologically distinct. For bacteria it is known that competition and fluctuating environments increase phenotypic diversity (Corno \& Jürgens 2006). However, in the specific case of Synechococcus it is still unknown, for example, if adaptation to low light (in order to survive at the limit of the photic zone) can be a force selecting an appropriate strain or if the adaptability of the genus itself is sufficient to let them survive in extreme conditions.

\section{MATERIAL AND METHODS}

\subsection{Study site and in situ measurements}

Lake Maggiore is a large $\left(212 \mathrm{~km}^{2}\right)$, deep $(372 \mathrm{~m})$, subalpine lake, which has been the site of limnological studies since the first half of the past century (Baldi et al. 1953; de Bernardi et al. 1988; Bertoni \& Callieri 1989; Callieri \& Piscia 2002). The lake recovered from the eutrophic state reached in the late 1970s (maximum in-lake TP concentration at winter mixing $\left.30 \mu \mathrm{g} \mathrm{l}^{-1}\right)$ and is now oligotrophic (TP around $10 \mu \mathrm{g} \mathrm{l}^{-1}$ ) (Calderoni et al. 2006).

Sampling was performed at the station of the maximum depth, which has been chosen as the reference station for a long-term study on the lake (http://www.ise. cnr.it/lter). Discrete samples were taken with a 5 litre Van Dorn bottle. Profiles of temperature and Photosynthetic Active Radiation (PAR) were obtained using a multiparameter probe (IDRONAUT, mod. OS316).

\subsection{Sampling}

We took samples in two periods of the year corresponding to the spring and late summer picocyanobacteria peaks, typical of deep, temperate oligotrophic lakes (Callieri \& Pinolini 1995; Padisák et al. 1997). In each period, sampling was performed once a week for three consecutive weeks (16-6, 22-6, 30-6 and 31-8, 8-9, 149) in order to follow the short-term evolution of picocyanobacteria assemblages. Two depths were chosen, namely $1 \%(8-15 \mathrm{~m})$ and $15 \%$ of surface PAR $(3 \mathrm{~m})$.

\subsection{Counting}

Picocyanobacteria were immediately preserved in formalin ( $2 \%$ final solution) cacodilate buffered, stored in darkness at $4^{\circ} \mathrm{C}$ and processed within two weeks. Counting was performed on polycarbonate filters (Nuclepore, $0.2 \mu \mathrm{m}$ pore size) by autofluorescence of phycoerythrin (Zeiss Axioplan microscope equipped with an HBO 100 W lamp, a Neofluar 100 x objective, $1.25 \mathrm{x}$ additional magnification, and filter sets for blue and green light excitation, Zeiss filter set 09: BP450-490, FT510, LP520, Zeiss filter set 14: LP510KP560, FT580, LP590). Cells were measured with an image analysis system (Image ProPlus sofware and CoolSNAP pro-cf videocamera; Media Cybernetics, Silver Spring, MD, USA). Cell volumes were transformed to carbon using a conversion factor of $200 \mathrm{fg} \mathrm{C}$ $\mu \mathrm{m}^{-3}$ (Weisse 1993).

\subsection{Chemical analyses}

Total Phosphorus (TP) and Total Nitrogen (TN) were determined according to A.P.H.A. (1985) after mineralization of the samples with persulfate-boric acid (Valderrama 1981). Soluble Reactive Phosphorus (SRP) was determined according to A.P.H.A. (1985) after samples filtration through GF/C (Whatman) filters.

The Total Inorganic Carbon (TIC) availability was determined from $\mathrm{pH}$ and alkalinity measurements. In order to determine the Chlorophyll $a(\mathrm{Chl} a$ ) content of picophytoplankton, up to $250 \mathrm{ml}$ of sampled water were filtered through a $2.0 \mu \mathrm{m}$ pore size polycarbonate filter $\left(\right.$ Osmonics $\left.{ }^{\mathrm{TM}}\right)$ and the filtrate was subsequently filtered through a $0.2 \mu \mathrm{m}$ pore size polycarbonate filter $\left(\right.$ Osmonics $\left.{ }^{\mathrm{TM}}\right)$. The Chlorophyll $a$ concentration was determined fluorometrically by Perkin-Elmer LS-2 Filter Fluorometer (Stainton et al. 1974) after pigment extraction with methanol (Talling \& Driver 1961; HolmHansen \& Riemann 1978).

\subsection{Primary production}

For each date, primary production (PP) was measured using the ${ }^{14} \mathrm{C}$ technique (Steeman-Nielsen 1951, 1952). Dark bottle measurements were substituted by the "time 0 " organic ${ }^{14} \mathrm{C}$ measurement by adding the isotope to the dark bottle and immediately filtering and analyzing (Fahnenstiel et al. 1994). Lake water was sampled before starting the incubations and 4 replicate vials $(25 \mathrm{ml}$ each) were immediately filled with lake water. We added $1.48 \mathrm{kBq} \mathrm{NaH}{ }^{14} \mathrm{CO}_{3} \mathrm{ml}^{-1}$ (Amersham) to each vial, and then incubated the samples in situ for 4 hours around noon. Incubations were carried out with the vials suspended at the two sampling depths in the euphotic zone. After incubation, $500 \mu 1$ aliquots were taken to check total activity. In order to estimate size fractionated primary productivity $(>2 \mu \mathrm{m}$ and $<2 \mu \mathrm{m}$ ) the samples were filtered using plastic disposable syringes and plastic $25 \mathrm{~mm}$ filter holders. Polycarbonate filters (Osmonics ${ }^{\mathrm{TM}}$ ) of $2 \mu \mathrm{m}$ were used for the autotrophic fraction $(>2 \mu \mathrm{m})$. The filtrate was concentrated on $0.22 \mu \mathrm{m}$ nitrocellulose membranes (Millipore $^{\mathrm{TM}}$ ). Filters were acidified with $200 \mu 11 \mathrm{~N} \mathrm{HCl}$ for 60 minutes in $20 \mathrm{ml}$ - scintillation vials. After adding $10 \mathrm{ml}$ of scintillation liquid the vials were counted in a Beckman LS3801 scintillation Counter. Photosynthetic carbon assimilation was calculated based on the proportion between ${ }^{14} \mathrm{C}$ uptake and TIC availability (SteemanNielsen 1951, 1952). 
Tab. 1. Sequences of primers used and relative target regions.

\begin{tabular}{llc}
\hline Primer & Sequence (5' to 3') & Target region \\
\hline CYA359F & GGG GAA TY T ${ }^{b}$ T TCC GCA ATG GG & $359-378$ \\
CYA781R(a) & GAC TAC TGG GGT ATC TAA TCC CAT T & $781-805$ \\
CYA781R(b) & GAC TAC AGG GGT ATC TAA TCC CTT T & $781-805$ \\
numbering refers to position on 16S rRNA of E.coli & \\
${ }^{b} \mathrm{Y}=\mathrm{C} / \mathrm{T}$ & & \\
\hline
\end{tabular}

\subsection{Nucleic acid extraction and PCR amplification}

We concentrated about $300 \mathrm{ml}$ of lake water from each environmental sample on $0.2 \mu \mathrm{m}$ sterile hydrophilic polyethersulfone Supor ${ }^{\circledR}$ (Gelman Laboratory) and kept at $-20^{\circ} \mathrm{C}$ in $2 \mathrm{ml}$ of lysis buffer $(50 \mathrm{mM}$ Tris, $40 \mathrm{mM}$ EDTA, $400 \mathrm{mM} \mathrm{NaCl}, 0,75 \mathrm{M}$ Sucrose; Giovannoni et al. 1990) for no longer than 2 months.

DNA used for DGGE protocols was extracted from the filters using the UltraClean Soil DNA Isolation Kit (MoBio) and cast through $1 \%(\mathrm{w} / \mathrm{v})$ agarose in TBE buffer for visual estimation under UV transillumination (Gel DOC XR System (Bio-Rad) with Quantity One ${ }^{\circledR}$ (Bio-Rad), after staining with ethidium bromide (EB).

For amplification of the $16 \mathrm{~S}$ rDNA, $20 \mathrm{nM}$ of primers CYA359F and equimolar mix of CYA781R(a) and CYA781R (b) (Tab. 1) (Nübel et al. 1997) were included in the reaction with approximately $50 \mathrm{ng}$ of DNA extracts and $25 \mu 1$ Taq PCR Master Mix Kit (QIAGEN), for a volume of $50 \mu \mathrm{l}$ of $0.2 \mu \mathrm{m}$ sterile filtered water. The amplification profile consisted of an initial denaturation at $96^{\circ} \mathrm{C}$ for 5 min followed by 10 touchdown cycles of $94^{\circ} \mathrm{C}$ for $45 \mathrm{~s}, 65^{\circ} \mathrm{C}\left(-1^{\circ} \mathrm{C}\right.$ each cycle $)$ for $45 \mathrm{~s}$ and $72^{\circ} \mathrm{C}$ for $2 \mathrm{~min}$, then 20 cyles of $94^{\circ} \mathrm{C}$ for $45 \mathrm{~s}$, $55^{\circ} \mathrm{C}$ for $45 \mathrm{~s}$ and $72^{\circ} \mathrm{C}$ for $2 \mathrm{~min}$ (Don et al. 1991 ; Muyzer et al. 1993). A final elongation step of $72^{\circ} \mathrm{C}$ for 5 min was performed. PCR reactant concentrations were as follows: $20 \mathrm{nM}$ each primer, $50 \mathrm{ng}$ DNA template and $25 \mu 1$ Taq PCR Master Mix Kit (QIAGEN), for a volume of $50 \mu \mathrm{l}$ of $0.2 \mu \mathrm{m}$ sterile filtered water.

\subsection{DGGE analysis and sequencing}

The PCR product was electrophoresed (for $16 \mathrm{~h}$ at $150 \mathrm{~V})$ through a polyacrylamide gel $(1 \mathrm{~mm})$ with 37 to $70 \%$ denaturing gradient, in which $100 \%$ is defined as $7 \mathrm{M}$ urea and $40 \%$ (vol/vol) formamide in a Bio-Rad DCode. The gel was then incubated for $20 \mathrm{~min}$ in $4^{\circ} \mathrm{C}$ in SYBR ${ }^{\circledR}$ Green I Nucleic Acid Gel Stain (Cambrex) dissolved in MilliQ water. Denatured DNA bands were detected under UV illumination with Gel DOC XR System (Bio-Rad) and elaborated by Quantity One ${ }^{\circledR}$ (Analyse Software, Bio-Rad).

A density profile through each lane was assessed, the bands detected (regarded as operational taxonomic units, OTUs) and the relative contribution of each band to the total band signal was calculated in the lane after applying a rolling disk as background subtraction. Bands with a relative intensity of $<0.5 \%$ of the total intensity of the lane were disregarded. A distance matrix of the lanes was calculated using the BrayCurtis Coefficient and a cluster (UPGMA, unweighted-pairgroup mean average) was inferred using the program MEGA3 (Molecular Evolutionary Genetic Analysis).

In order to sequence the DGGE bands, we excised the most prominent bands of the 12 lanes of SYBR ${ }^{\circledR}$ Green-stained DGGE gel using a sterile scalpel and DNA eluted overnight at $4^{\circ} \mathrm{C}$ in $500 \mu 1$ of TE buffer (10 $\mathrm{mM}$ Tris-HCl, EDTA $1 \mathrm{mM}$ ) (Nübel et al. 1997). One microliter of each solution containing excised bands was re-amplified using the same primers and the same PCR conditions, as described above. Next, we sequenced the PCR products using the forward primer under the following conditions: $2.5 \mu \mathrm{l}$ primer CYA359F $(1 \mu \mathrm{M}), 2 \mu \mathrm{l}$ of BigDye ${ }^{\circledR}$ Terminator v1.1 Cycle Sequencing Kit (Applied Biosystems), $4 \mu 1$ Tris buffer $(2.5 \mathrm{x}), 3 \mu \mathrm{l}$ preamplified DNA, and $8.5 \mu \mathrm{l}$ of MilliQ water to a final volume of $20 \mu \mathrm{l}$ (termocycling conditions: $96^{\circ} \mathrm{C}$ for 1 min, 30 cycles at $96^{\circ} \mathrm{C}$ for $10 \mathrm{~s}, 50^{\circ} \mathrm{C}$ for $5 \mathrm{~s}$ and $60^{\circ} \mathrm{C}$ for $4 \mathrm{~min}$ ). The final PCR products were purified using the QIAquick PCR purification kit (QIAGEN). Sequencing was performed in a ABI PRISM 310 (Applied Biosystems) sequencer.

\section{RESULTS}

\subsection{In situ measurements and ecological parameters}

Temperature and light profiles (Fig. 1) at the six sampling dates indicate two distinct hydrologic situations: in spring, the thermocline depth was shallower than the depth of $1 \%$ of surface PAR (limit of the photic zone), while in late summer the thermocline depth extended deeper than the photic zone. The exception was on September 8, when the euphotic zone extended to $18 \mathrm{~m}$, much deeper than the thermocline depth. In late summer the thermocline was much more pronounced than in spring. In general, during spring samplings the Synechococcus assemblages living at $1 \%$ of surface PAR were confined to the bottom of the photic zone whereas in late summer the assemblages living in the photic zone stayed in the mixing layer, thus having the possibility to be transported into the near surface zone. 
Tab. 2. Main chemical parameters measured in Lake Maggiore at $15 \%$ (upper panel) and at $1 \%$ of surface PAR (lower panel). TN =Total Nitrogen, SRP = Soluble Reactive Phosphorus, $\mathrm{TP}=$ Total Phosphorus, TIC $=$ Total Inorganic Carbon, PAR $=$ Photosynthetic Active Radiation.

\begin{tabular}{|c|c|c|c|c|c|c|c|c|}
\hline $\begin{array}{l}15 \% \\
\text { PAR }\end{array}$ & $\begin{array}{c}\mathrm{TN} \\
\left(\mathrm{mg} \mathrm{l}^{-1}\right)\end{array}$ & s.d. & $\begin{array}{c}\mathrm{SRP} \\
\left(\mu \mathrm{g} \mathrm{l}^{-1}\right)\end{array}$ & s.d. & $\begin{array}{c}\mathrm{TP} \\
\left(\mu \mathrm{g}^{-1}\right)\end{array}$ & s.d. & $\begin{array}{c}\text { TIC } \\
\left(\mathrm{mg} \mathrm{l}^{-1}\right)\end{array}$ & $\begin{array}{c}\text { PAR } \\
\left(\mu \mathrm{mol} \mathrm{m}^{-2} \mathrm{~s}^{-1}\right)\end{array}$ \\
\hline $16-06-04$ & 0.98 & 0.08 & 1.04 & 1.13 & 9.70 & 1.35 & 10.01 & 154 \\
\hline $22-06-04$ & 0.97 & 0.07 & 2.11 & 0.72 & 12.03 & 0.97 & 9.79 & 52 \\
\hline 30/06/04 & 0.84 & 0.05 & 2.84 & 1.65 & 12.52 & 2.17 & 9.89 & 872 \\
\hline 31/08/04 & 0.60 & 0.03 & 1.89 & 0.72 & 9.94 & 0.37 & 8.85 & 82 \\
\hline 08/09/04 & 0.79 & 0.01 & 1.74 & - & 6.64 & 1.09 & 9.35 & 399 \\
\hline $14 / 09 / 04$ & 0.75 & 0.04 & 1.02 & - & 10.77 & 3.56 & 9.62 & 395 \\
\hline $\begin{array}{l}1 \% \\
\text { PAR } \\
\end{array}$ & $\begin{array}{c}\mathrm{TN} \\
\left(\mathrm{mg} \mathrm{l}^{-1}\right)\end{array}$ & s.d. & $\begin{array}{c}\mathrm{SRP} \\
\left(\mu \mathrm{g} \mathrm{l}^{-1}\right)\end{array}$ & s.d. & $\begin{array}{c}\mathrm{TP} \\
\left(\mu \mathrm{g} \mathrm{l}^{-1}\right)\end{array}$ & s.d. & $\begin{array}{c}\mathrm{TIC} \\
\left(\mathrm{mg} \mathrm{l}^{-1}\right)\end{array}$ & $\begin{array}{c}\text { PAR } \\
\left(\mu \mathrm{mol} \mathrm{m}^{-2} \mathrm{~s}^{-1}\right)\end{array}$ \\
\hline $16-06-04$ & 0.98 & 0.02 & 0.46 & 1.03 & 9.65 & 1.11 & 9.69 & 15 \\
\hline $22-06-04$ & 0.95 & 0.02 & 2.03 & - & 12.42 & 0.30 & 9.65 & 1 \\
\hline 30/06/04 & 0.93 & 0.07 & 3.27 & 0.41 & 10.41 & 0.51 & 10.02 & 25 \\
\hline $31 / 08 / 04$ & 0.81 & 0.06 & 0.01 & - & 10.96 & 0.34 & 9.17 & 3 \\
\hline 08/09/04 & 0.89 & 0.03 & 1.09 & 0.10 & 8.29 & 2.90 & 8.60 & 32 \\
\hline $14 / 09 / 04$ & 0.81 & 0.03 & 0.01 & - & 11.64 & 1.93 & 9.40 & 75 \\
\hline
\end{tabular}

\section{PAR (\%)}

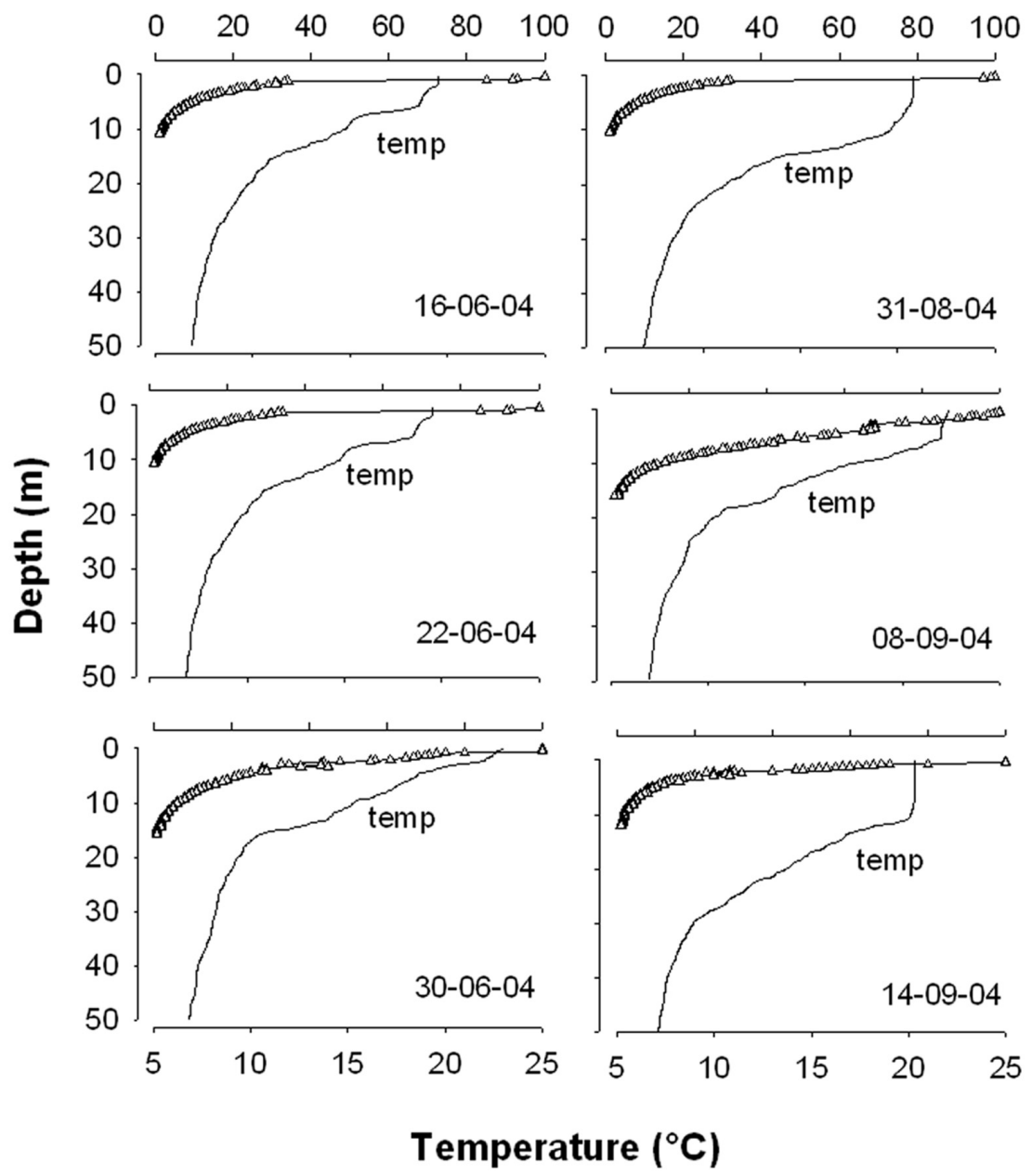

Fig. 1. Profiles of temperature (line) and percentage of surface PAR (triangles) in the two study periods, in Lake Maggiore 2004. 
On two occasions, we found multiple thermoclines (on 29 June: 2, 9, 14 m; on 8 September: 9, $18 \mathrm{~m}$ ), which is a condition often encountered in oligomictic Lake Maggiore (Barbanti \& Ambrosetti 1989).

The chemical analyses performed in the two periods (Tab. 2) showed similar characteristics of lake water at the two depths and a more pronounced difference of the SRP between June and September. A well-defined period of P limitation was evident in September with SRP concentrations below detection limits. Nitrogen was never limiting, and ranged between 600-980 $\mu \mathrm{g} \mathrm{l}^{-1}$. Inorganic carbon was around $9-10 \mathrm{mg} \mathrm{l}^{-1}$, indicating favourable conditions for primary production.

Synechococcus abundances (Fig. 2A) were not statistically different at the two depths ( $t$-test for dependent variables, df $5, \mathrm{P}=0.44$ and $\mathrm{P}=0.30$ respectively). The marked variability observed during the study periods indicates a weekly variation of cell number. The peak of cell number was reached in September at $3 \mathrm{~m}\left(160 \times 10^{3}\right.$ cell $\left.\mathrm{ml}^{-1}\right)$.

The mean cell volume was statistically different $(t$ -
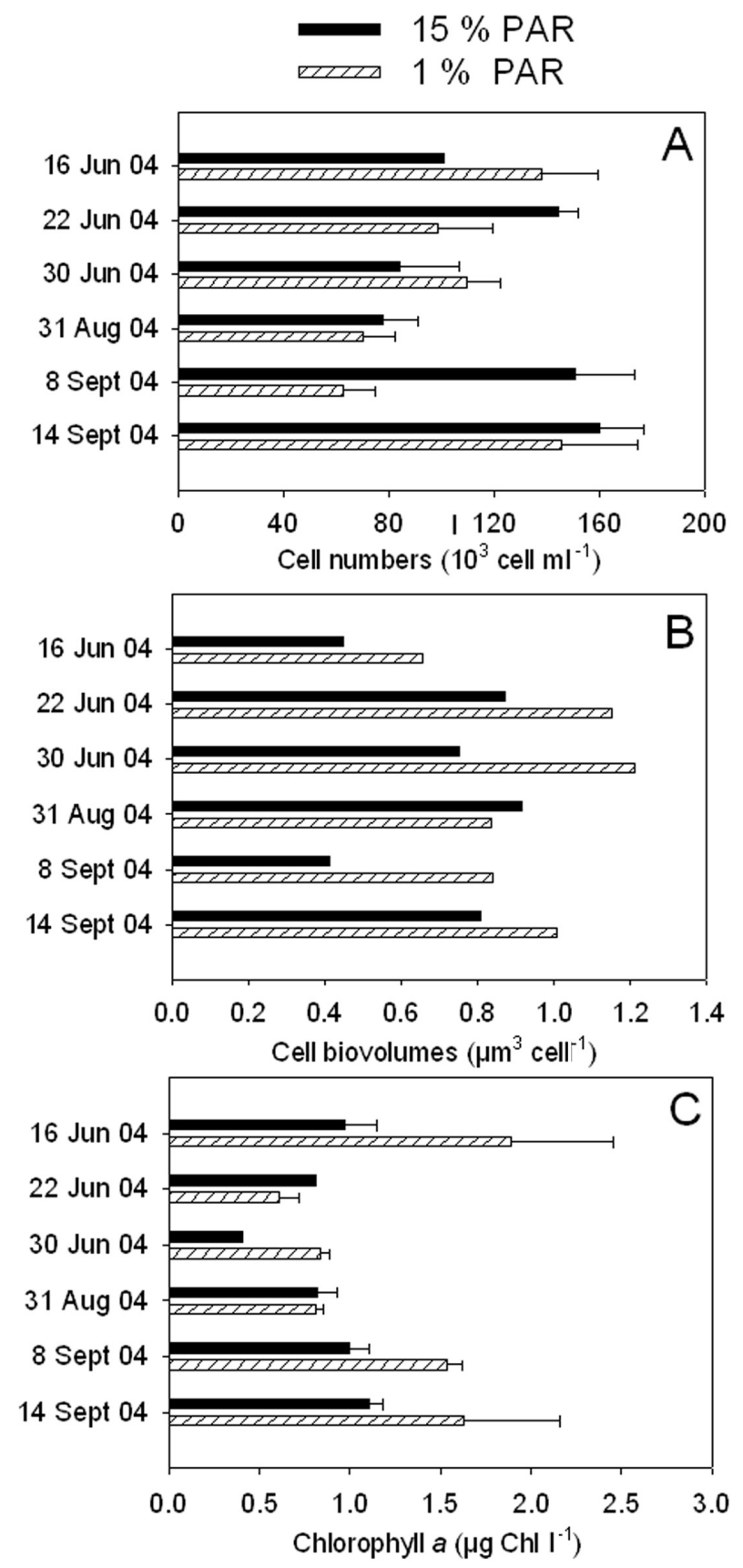

Fig. 2. Numbers of picocyanobacteria $\left(10^{3}\right.$ cells $\left.\mathrm{ml}^{-1}\right)(\mathrm{A})$, cell volume $\left(\mu \mathrm{m}^{3}\right.$ cell-1) (B), Chlorophyll $a$ concentrations $\left(\mu \mathrm{g} \mathrm{l}{ }^{-1}\right)(\mathrm{C})$, at the two depths during the two study periods, in Lake Maggiore 2004. 
test for dependent variables, $\mathrm{df} 5, \mathrm{P}=0.02)$ at the two depths, with the larger cells at $1 \%$ PAR $(0.70$ and 0.95 $\mu \mathrm{m}^{3}$ cell $^{-1}$ at 3 and $10 \mathrm{~m}$ respectively) (Fig. 2B)

Chl $a$ concentration (Fig. 2C) results were highly variable with a generalized concentration increase at $1 \%$ of surface PAR. Nevertheless, the differences between the two depths were not significant ( $t$-test for dependent variables, df $14, \mathrm{P}=0.158)$. The picocyanobacteria chlorophyll-specific production (Fig. 3, upper panel) showed a significant difference among depths $(t$-test, $\mathrm{df}$ $23, \mathrm{P}=0.0001)$. At $15 \%$ of surface PAR the values were always higher and ranged from 0.7 to $5.4 \mathrm{mg} \mathrm{C}\left(\mathrm{mg} \mathrm{Chl}^{-1}\right.$ $\mathrm{h}^{-1}$, as compared to a variation between 0.17 and $0.81 \mathrm{mg}$ $\mathrm{C}(\mathrm{mg} \mathrm{Chl})^{-1} \mathrm{~h}^{-1}$ at $1 \%$ of surface PAR. Picocyanobacteria efficiency, i.e. the production per unit $\mathrm{Chl}$ and unit mole of photons was significantly higher at $1 \%$ of PAR (mean: $13.4 \mathrm{mg} \mathrm{C}\left(\mathrm{mg} \mathrm{Chl}^{-1} \mathrm{~mol}^{-1} \mathrm{~m}^{-3}\right)$ than at $15 \%$ of PAR (mean: $6.5 \mathrm{mg} \mathrm{C}(\mathrm{mg} \mathrm{Chl})^{-1} \mathrm{~mol}^{-1} \mathrm{~m}^{-3}$ ) (Fig. 3, lower panel). No significant difference was found between spring and late summer samples.

\subsection{Genotypic classification}

DGGE profiles showed a relatively low number of bands through both seasons, never exceeding 10 different OTUs in a single sample with an average value of OTU richness of 6.25 OTUs per lane. Communities at $1 \%$ PAR showed relatively constant richness levels, ranging between 5 and 8 OTUs, while communities at $15 \%$ PAR exhibited more unstable values, ranging from 3 to 10 OTUs per sample (Fig. 4). Some very clear and pronounced bands were common to all samples while others were only present in spring samples. We found a rather constant number of taxonomic units (DNA bands) in the 3 consecutive samples from each period, at the two depths, suggesting slight differences between depths in the same period.
From the density profile of the DGGE lanes, we used the relative contribution of each band to the total band signal to calculate the distance matrix and produce a cluster analysis (Fig. 4). The cluster displayed two groups at 0.21 distance. The sample from August $31(3 \mathrm{~m})$ was an outgroup, because its analysis was very poor due to problems with the PCR amplification of the extracted DNA. The two clusters demonstrated the difference between the spring and late summer fingerprinting image of the picocyanobacteria community in Lake Maggiore. On the other hand, in spring, the relative OTU richness (Fig. 4) was significantly higher (Paired ttest, $\mathrm{P}=0.02$ ) at the depth of $15 \%$ surface PAR as compared to the $1 \%$. In autumn, the difference between the depths was not significant (Paired t-test, $\mathrm{P}=0.07$ ).

When excised and sequenced, the more pronounced spring bands showed $100 \%$ similarity to Synechococcus LM94, MW76B2 and MW15-2 which are phycoerythrin-rich strains of subalpine cluster I, Group B (Crosbie et al. 2003a). One band common both to late summer and spring was $100 \%$ similar to Synechococcus MH301, near subalpine cluster II.

\section{DISCUSSION}

Picocyanobacteria in Lake Maggiore have been studied since 1992 (Callieri \& Pinolini 1995) and represent $85-90 \%$ of total picophytoplankton number (Callieri \& Piscia 2002). They are Synechococcus-type single celled in spring and tend to form small microcolonies in late summer (Passoni \& Callieri 2001). During this study picocyanobacteria cell volumes were different at the two depths examined, and the cells at $15 \%$ of surface PAR $(3 \mathrm{~m})$ were significantly smaller than those at $1 \%$ of surface PAR. This morphological difference along the photic zone could indicate either a different metabolic state of the cells in the vertical gradient (cells with low divi-

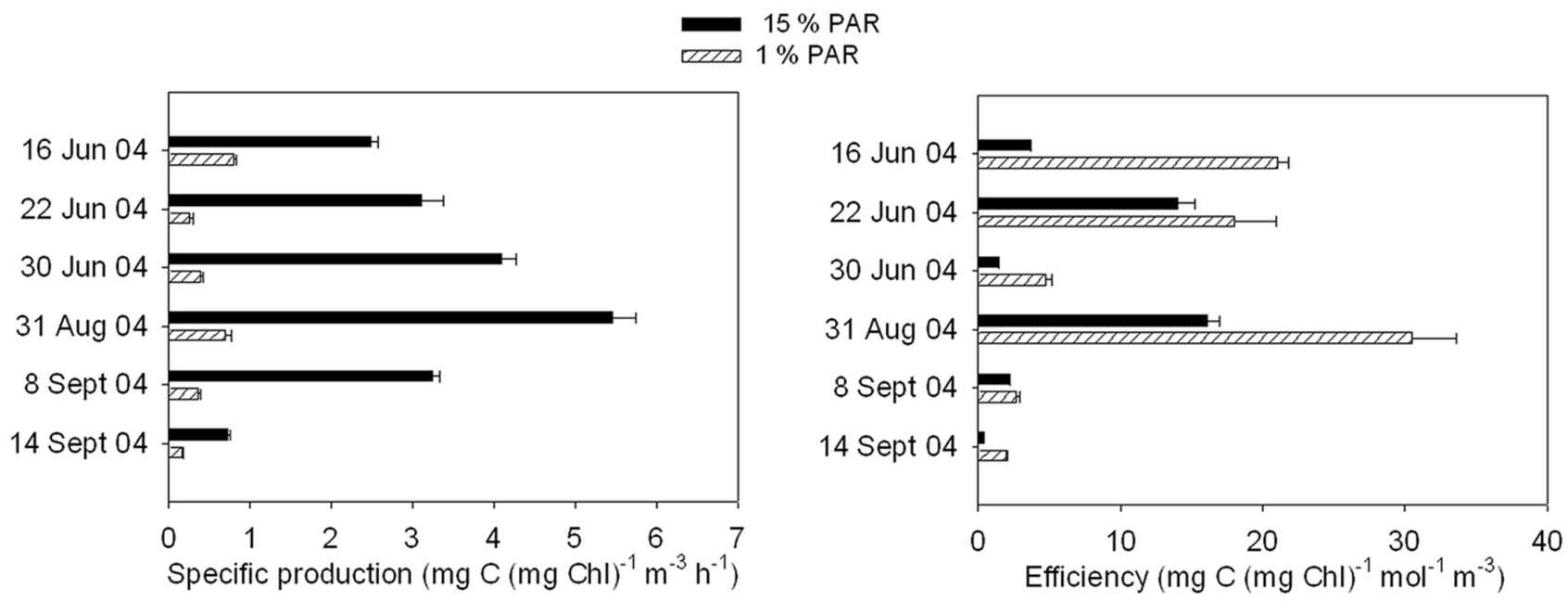

Fig. 3. Chlorophyll specific production $\left(\mathrm{mg} \mathrm{C}(\mathrm{mg} \mathrm{Chl})^{-1} \mathrm{~m}^{-3} \mathrm{~h}^{-1}\right.$, left) and photosynthetic efficiency $\left(\mathrm{mg} \mathrm{C}\left(\mathrm{mg} \mathrm{Chl}^{-1} \mathrm{~mol}^{-1} \mathrm{~m}^{3}, \mathrm{right}\right)\right.$, measured in the pico fraction at the two depths on six dates, in Lake Maggiore 2004. 
sion rate which slowly enlarge their volume but do not divide), or even the presence of different strains. Picocyanobacteria assemblages of the two depths in Lake Maggiore also showed differences in chlorophyll $a$ concentrations, as well as in photosynthetic characteristics. The surface communities were more productive but less photosynthetically efficient. No difference was found in morphology and in photosynthetic characteristics of Synechococcus cells between the spring and late summer samplings. Therefore, working from the measures of functional activity of picocyanobacteria (Chl $a$ content, cell volume, cell production and efficiency) we expected to find a pronounced difference in OTU's diversity at different niches along the water column, rather than between the two different seasons.

However, the genotypic analyses showed opposite signals. The DGGE fingerprints proved two different clusters that markedly differentiate the relative OTU diversity of the spring and late summer picocyanobacteria. The results of the sequenced bands yielded evidence of the presence of one OTU that was phylogenetically similar to group B of the subalpine cluster I, which was only present in spring (see Crosbie et al. 2003a). Another OTU sequenced was common to all the spring and late summer samples. In contrast, the OTUs colonizing different niches in the water column vertical profile did not show any significant clustering. In other words, different picocyanobacteria ecotypes (i.e. with distinct photosynthetic characteristics), met along the photic zone and did not form clustered groups. Instead, the OTU richness was significantly different at the two depths in spring, reaching the highest values (10) at 15 $\%$ of surface PAR. This result is partly explained by the hydrologic situation of the spring period, when the shallow thermocline created a density barrier between the two depths. Actually, in spring, notwithstanding the lower cell abundances in the shallower layer, the picocyanobacteria community was characterized by a higher richness and was composed of smaller, more photosynthetically active cells. The absence of a true mixing layer in spring actually influences the number of OTUs present at the shallower layer, enabling the increase of species coexistence. This situation was not observed in late summer when the mixing layer extended deeper than the photic zone and allowed cells to be transported and mixed through the entire photic zone. We know that temperature gradient and water column stability influence picocyanobacterial community dynamics in both
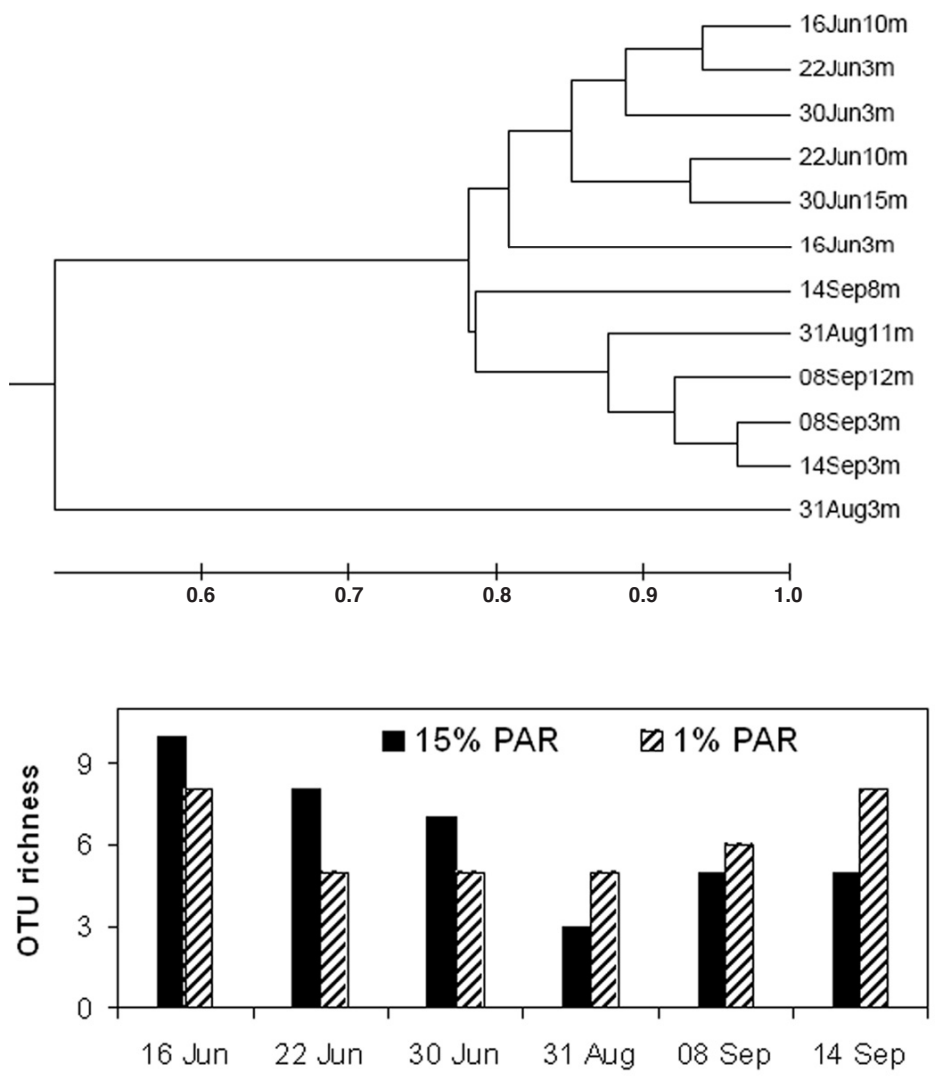

Fig. 4. Cluster analysis of picocyanobacteria communities based upon significant ( $>0.5 \%$ of total lane brightness) DGGE bands. Similarities are expressed as the Bray-Curtis Coefficient, which compares the relative contribution of single OTUs to the total amplified DNA of each band, when making pairwise comparisons between samples. Clustering was performed with UPGMA. Richness in bands of each sample is reported by grouping $15 \%$ PAR $(3 \mathrm{~m})$ samples and $1 \%$ PAR (between 8 and $15 \mathrm{~m} \mathrm{depth}$ ). 
marine and freshwater environments (Camacho et al. 2003; Fuller et al. 2005).

In Lake Constance, seasonal dynamics of population and subpopulations of Synechococcus-type picocyanobacteria were demonstrated (Becker et al. 2002). In laboratory experiments using Synechococcus strains isolated from Lake Constance in spring and late summer (Postius et al. 1998) it has been found that changing the environmental conditions may cause dominance of the better adapted organisms. Nevertheless, to date, the partitioning of specific Synechococcus clades or ecotypes into specific niches in situ has not yet been demonstrated in freshwater.

Using dot blot hybridization technique, the predominance of genotypes from a single clade of Synechococcus population was demonstrated in the Red Sea (Fuller et al. 2003). The other cultures isolated, lacking PE, represented only a minor component in the natural environment. This community composition, which was rather homogeneous in vertical space, turned out to be composed of a few strains, dominant over the others, as a result of niche differentiation.

Recently was found that the Prochlorococcus HL (high light) ecotype (sensu Moore et al. 1998) was dominant over the season, while the LL (low light) ecotype was negligible and only appeared in late summer below $50 \mathrm{~m}$ (Fuller et al. 2005). This indicates that different ecotypes can coexist, but not necessarily dominate, at the same time at different depths; they appear to exploit a particular refuge niche in different seasonal periods. This hypothesis is also based on the evidence that picocyanobacteria are the winning competitors for phosphorus but at the cost of a selection towards the more adapted ecotypes.

Our data showed a difference in SRP concentrations in spring and late summer, with strong P-limitation conditions in September. In that month, total phytoplankton biomass was lower than in spring (Morabito et al. 2005) and picocyanobacteria represented more than $50 \%$ of total autotrophic biomass (S. Galafassi, Thesis). The ecological conditions in late summer appeared distinct from those in spring and potentially able to select different genotypes, in accordance with our results of OTU's diversity. Conversely, the photosynthetic characteristics and the physiological traits of spring and late summer picocyanobacteria assemblages were highly variable inside the two periods and showed no significant difference between seasons.

The initial hypothesis of a genetically distinct Synechococcus population located at different depths along the water column according to their most favourable temperature and light conditions appears improbable. Instead, it is likely that picocyanobacterial strains coexist in the vertical gradient, rapidly acclimate (without an actual genetic adaptation) in the mixing layer and perform differently in the microhabitats. In particular, the OTU richness of spring samples was higher in the upper layer, above the thermocline. This study also revealed the presence of a spring picocyanobacterial strain affiliated to the subalpine cluster I, which disappeared in late summer, as well as a ubiquitous strain affiliated to subalpine cluster II.

Our results should be confirmed by further studies performed over an entire year. The importance of longterm molecular studies has been recently emphasized (Fuller et al. 2005) as critical to the better interpretation of the succession of subpopulations of picocyanobacteria.

\section{CONCLUSIONS}

In conclusion, our study on the photosynthetic and genetic characteristics of Synechococcus has shown that picocyanobacteria near the surface and at the deeper edge of the photic zone photosynthesize with different efficiency. Nevertheless, fingerprinting analyses of these samples did not reveal any relevant difference in OTU diversity. In spring, with a shallow thermocline, OTU richness was different at the two depths. In particular, richness was higher in the shallower layer, where the cells were more photosynthetically active and smaller, than in the deeper one.

The sequences obtained from DGGE excised bands revealed the presence of one spring OTU phylogenetically similar to the group B of the subalpine cluster I and of one OTU common to spring and late summer samples. This confirms that in Lake Maggiore, like in other subalpine lakes, different Synechococcus strains may occur in spring and in late summer.

\section{ACKNOWLEDGEMENTS}

We thank Mario Contesini for help with sampling, and Paola Giacomotti for analyses of the inorganic carbon. We are also grateful to the laboratories of the ICM (Istituto Cantonale di Microbiologia), Bellinzona ( $\mathrm{CH})$, where part of the genetic analyses were performed.

\section{REFERENCES}

A.P.H.A., A.W.W.A., W.P.C.F. 1985. Standard methods for the examination of water and wastewater. (American Public Health Association, Washington.)

Baldi, E., V. Tonolli \& L. Tonolli Pirocchi. 1953. La differente evoluzione di due laghi già costituenti un unico bacino: il Lago Maggiore e il Lago di Mergozzo. Mem. Ist. ital. Idrobiol., 7: 49-107.

Becker, S., M. Fahrbach, P. Böger \& A. Ernst. 2002. Quantitative tracing, by Taq nuclease assays, of a Synechococcus ecotype in a highly diversified natural population. Appl. Environ. Microbiol., 68: 4486-4494.

Barbanti, L. \& W. Ambrosetti. 1989. The physical limnology of Lago Maggiore: a review. Mem. Ist. ital. Idrobiol., 46: 41-68.

Bertoni, R. \& C. Callieri. 1989. Organic matter and decomposers in Lago Maggiore: a pluriannual study. Mem. Ist. ital. Idrobiol., 46: 145-172.

Calderoni, A., M. Rogora, A. Pranzo \& G. Tartari. 2006. Chimica lacustre. In: C.N.R. - I.S.E. Sede di Verbania. Ricerche sull'evoluzione del Lago Maggiore. Aspetti limnologici. Programma quinquennale 2003-2007. Campagna 
2005. Commissione Internazionale per la protezione delle acque italo-svizzere (Ed.): 45-53.

Callieri, C. 1996. Extinction coefficient of red, green and blue light and its influence on picocyanobacterial types in lakes at different trophic levels. Mem. Ist. ital. Idrobiol., 54: 135-142.

Callieri, C. \& M.L. Pinolini. 1995. Picoplankton in Lake Maggiore, Italy. Internat. Rev. Ges. Hydrobiol., 80: 491-501.

Callieri, C. \& R. Piscia. 2002. Photosynthetic efficiency and seasonality of autotrophic picoplankton in Lago Maggiore after its recovery. Freshwater Biol., 47: 941-956.

Camacho, A, M.R. Miracle \& E. Vicente. 2003. Which factors determine the abundance and distribution of picocyanobacteria in inland waters? A comparison among different types of lakes and ponds. Arch. Hydrobiol., 157: 321-338.

Corno, G. \& K. Jürgens. 2006. Direct and indirect effects of protist predation on population size structure of a bacterial strain with high phenotypic plasticity. Appl. Environ. Microbiol., 72: 78-86.

Crosbie, N.D., M. Pöckl \& T. Weisse. 2003a. Dispersal and phylogenetic diversity of nonmarine picocyanobacteria, inferred from 16S rRNA gene and cpcBA-intergenic spacer sequence analyses. Appl. Environ. Microbiol., 69: 5716-5721.

Crosbie, N.D., K. Teubner \& T. Weisse. 2003b. Flow-cytometric mapping provides novel insights into the seasonal and vertical distributions of freshwater autotrophic picoplankton. Aquat. Microb. Ecol., 33: 53-66.

de Bernardi, R., G. Giussani, M. Manca \& D. Ruggiu. 1988. Long-term dynamics of plankton communities in Lago Maggiore. Verh. Internat. Verein. Limnol., 23: 729-733.

Don, R.H., P.T. Cox, B.J. Wainwright, K. Baker \& J.S. Mattick. 1991. Touchdown PCR to circumvent spurious priming during gene amplification. Nucl. Ac. Res., 19: 4008.

Ernst, A., K. Becker, S. Hennes \& C. Postius. 2000. Is there a succession in the autotrophic picoplankton of temperate zone lakes? In: C.R. Bell, M. Brylinski \& P. Johnson-Green (Eds), Microbial Biosystems: New Frontiers. Proceeding of the $8^{\text {th }}$ International Symposium on Microbial Ecology. Atlantic Canada Society for Microbial Ecology: Halifax Canada: 623-629.

Ernst, A., S. Becker, V.I.A. Wollenzien \& C. Postius. 2003. Ecosystem dependent adaptive radiations of picocyanobacteria inferred from $16 \mathrm{~S}$ rRNA and ITS-1 sequence analysis. Microbiology, 149: 217-228.

Fahnenstiel, G.L., D.G. Redalje \& S.E. Lohrenz. 1994. Has the importance of photoautotrophic picoplankton been overestimated? Limnol. Oceanogr., 39: 432-438.

Fuller, N.J., D. Marie, F. Partensky, D. Vaulot, A.F. Post \& D. Scanlan. 2003. Clade-specific 16S Ribosomal DNA oligonicleotides reveal the predominance of a single Synechococcus clade throughout a stratified water column in the red sea. Appl. Environ. Microbiol., 69: 2430-2443.

Fuller, N.J., N.J. West, D. Marie, M.Yallop, T. Rivlin, A.F. Post \& D. Scanlan. 2005. Dynamics of community structure and phosphorus status of picocyanobacterial populations in the Gulf of Aqaba, Red Sea. Limnol. Oceanogr., 50: 363-375.

Fuller, N.J., G.A. Tarran, M. Yallop, K.M. Orcutt \& D. Scanlan. 2006. Molecular analysis of picocyanobacterial community structure along an Arabian Sea transect reveals distinct spatial separation of lineages. Limnol. Oceanogr., 51: 2515-2526.

Giovannoni, S.J., E.F. Delong, T.M. Schmidt \& N.R. Pace. 1990. Tangential flow filtration and preliminary phylogenetic analysis of marine picoplankton. Appl. Environ. Microbiol., 56: 2572-2575.

Hauschild, C.A., H.J.G McMurter \& F.R. Pick. 1991. Effect of spectral quality on growth and pigmentation of picocyanobacteria. J. Phycol., 27: 698-702.

Holm Hansen, O. \& B. Riemann. 1978. Chlorophyll $a$ determination: improvements in methodology. Oikos, 30: 438-447.

Komárková, J. 2002. Cyanobacterial picoplankton and its colo- nial formations in two eutrophic canyon reservoirs (Czech Republic). Arch. Hydrobiol., 154: 605-623.

Moore, L., G. Roca \& S.W. Chisholm. 1998. Physiology and molecular phylogeny of coexisting Prochlorococcus ecotypes. Nature, 393: 464-467.

Morabito, G., P. Panzani \& A. Oggioni. 2005. Popolamenti planctonici. Indagini sul fitoplancton. In: C.N.R. - I.S.E. Sede di Verbania. Ricerche sull'evoluzione del Lago Maggiore. Aspetti limnologici. Programma quinquennale 2003-2007. Campagna 2004. Commissione Internazionale per la protezione delle acque italo-svizzere (Ed.): 53-58.

Muyzer, G., E.C. De Waal \& A.G. Uitterlinden. 1993. Profiling of Complex Microbial Populations by Denaturing Gradient Gel Electrophoresis Analysis of Polymerase Chain Reaction-Amplified Genes Coding for 16S rRNA. Appl. Environ. Microbiol., 59: 695-700.

Nübel, U., F. Garcia-Pichel \& G. Muyzer. 1997. PCR primers to amplify $16 \mathrm{~S}$ rRNA genes from Cyanobacteria. Appl. Environ. Microbiol., 63: 3327-3332.

Padisák, J., L. Krienitz, R. Koschel \& J. Nedoma. 1997. Deeplayer autotrophic picoplankton maximum in the oligotrophic Lake Stechlin, Germany: origin, activity, development and erosion. Eur. J. Phycol., 32: 403-416.

Passoni, S. \& C. Callieri. 2001. Picocyanobacteria single forms, aggregates and microcolonies: survival strategy or species succession? Verh. Internat. Verein. Limnol., 27: $1879-1883$.

Postius, C., U. Kenter, A. Wacker, A. Ernst \& P. Böger. 1998. Light causes selection among two phycoerythryn-rich Synechococcus isolates from Lake Constance. FEMS Microbiol. Ecol., 25: 171-178.

Robertson, B.R., N.N. Tezuka \& M.M. Watanabe. 2001. Phylogenetic analyses of Synechococcus strains (cyanobacteria) using sequences of the $16 \mathrm{~S} \mathrm{rDNA}$ and part of the phycocyanin operon reveal multiple evolutionary lines and reflect phycobilin content. Internat. J. Syst. Evol. Microbiol., 51: 861-871.

Stainton, M.P., M.J. Capel \& F.A.J. Armstrong. 1974. The chemical analysis of freshwater. Environmental Canadian Special Publication, 25.

Steeman Nielsen, E. 1951. Measurement of the production of organic matter in the sea by means of carbon-14. Nature, 167: 684-685.

Steeman Nielsen, E. 1952. The use of radioactive carbon $\left({ }^{14} \mathrm{C}\right)$ for measuring organic production in the sea. J. Cons. Internat. Expl. Mer, 18: 117-140.

Stockner, J., C. Callieri \& G. Cronberg. 2000. Picoplankton and other non-bloom forming cyanobacteria in lakes. In: B. Whitton \& M. Potts (Eds), Ecology of Cyanobacteria: Their Diversity in Time and Space. Kluwer Academic Publishers: 195-238.

Talling, J.F. \& D. Driver. 1961. Some problems in the estimation of chlorophyll $a$ in phytoplankton. In: Proceedings of the Conference on Primary Productivity Measurement. Honolulu: 142-146.

Valderrama, J.C. 1981. The simultaneous analysis of total nitrogen and total phosphorus in natural waters. Mar. Chem., 10: 109-122.

Vörös, L., C. Callieri, K.V. Balogh \& R. Bertoni. 1998. Freshwater picocyanobacteria along trophic gradient and light quality range. Hydrobiologia, 369/370: 117-125.

Weisse, T. 1993. Dynamics of autotrophic picoplankton in marine and freshwater ecosystems. In: J.C. Jones (Ed), Advances in Microbial Ecology. 13. Plenum Press, New York: $327-370$

Received: October 2007

Accepted: December 2007 